\title{
How Perceived Usefulness and Perceived Ease of Use Affecting Intent to Repurchase?
}

\author{
Keni Keni \\ Fakultas Ekonomi dan Bisnis, Universitas Tarumanagara \\ Email: \\ keni@fe.untar.ac.id
}

\begin{abstract}
This study was commenced in order to determine whether or not perceived usefulness and perceived ease of use positively affecting consumers' intention to repurchase, both in a direct and indirect manner through both trust and customer satisfaction. A sum of 250 respondents joined this study, while a total of 236 data were deemed usable to be further processed and analyzed in this study. Survey method was applied in this study, in which all of the data gathered from the respondents using questionnaires which were distributed both personally and electronically. All of the data then were analyzed using PLSSEM method. In accordance with the results, author conclude that both perceived usefulness and perceived ease of use play a significant and important role in affecting consumers' intention to repurchase, both directly and indirectly toward customer satisfaction and trust, in which trust plays a stronger role as a mediator as compared to satisfaction.
\end{abstract}

Keywords: Perceived Usefulness, Perceived Ease of Use, Trust, Customer Satisfaction, Repurchase Intention.

\begin{abstract}
Abstrak: Penelitian ini dilakukan guna mengetahui apakah perceived usefulness dan perceived ease of use memiliki pengaruh yang signifikan di dalam mempengaruhi intensi konsumen untuk kembali membeli ataupun menggunakan produk dari perusahaan yang sama, baik secara langsung ataupun tidak langsung melalui trust dan customer satisfaction. Sebanyak 250 responden berpartisipasi pada penelitian ini, dimana sebanyak 236 data dinyatakan valid dan reliabel untuk diproses. Metode survei diaplikasikan pada penelitian ini, dimana, seluruh data dikumpulkan melalui media kuesioner yang disebarkan secara elektronik dan fisik kepada responden. Seluruh data yang terkumpul dianalisis dengan pendekatan PLS-SEM. Berdasarkan hasil analisis data, penulis menyimpulkan bahwa perceived usefulness dan perceived ease of use memiliki peranan yang signifikan di dalam mempengaruhi intensi konsumen untuk kembali membeli ataupun menggunakan suatu produk dari perusahaan yang sama, baik secara langsung ataupun tidak langsung melalui trust dan satisfaction. Selain itu, ditemukan juga bahwa trust memiliki pengaruh yang lebih kuat di dalam memediasi hubungan antara variabel-variabel eksogen dengan variabel endogen yang diteliti.
\end{abstract}

Kata kunci: Perceived Usefulness, Perceived Ease of Use, Trust, Customer Satisfaction, Repurchase Intention. 


\section{INTRODUCTION}

E-Commerce had grown to become one of the fastest growing sector, not only in Asia, but also in the World. Based on the data published by one of the world's leading statistical website, Statista (Statista, 2020), the number of worldwide e-commerce sales from the retail sector had been progressively and significantly increasing for the past 5 years, in which, the total worldwide e-commerce sales had been increasing from a total of US $\$ 1.336$ Trillion in 2014 to a staggering amount of US\$3.53 Trillion in 2019. Furthermore, this figure were projected to further increase to US\$6.542 Trillion in 2023. Based on these data, then it was understandable of why e-comemrce had long been perceived by many as one of the most dominant, fastest growing sector in the world, at least for the last 8 years as compared to the other sectors or industries.

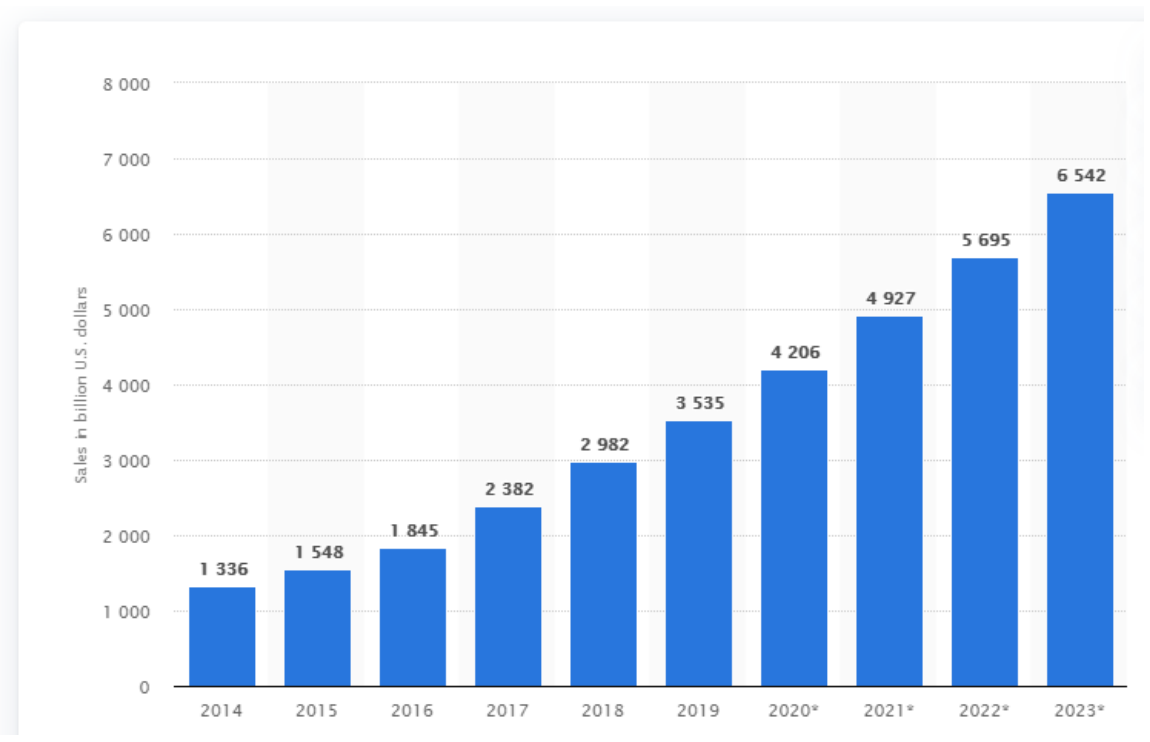

Figure 1. Worldwide Retail E-Commerce Sales (In Billion US. Dollars) Source: Statsta (2020)

As with the other industries or sectors, one of the factor which could explain how this sector (e-commerce) could grow rapidly in an expontential and staggering rate (along with the increasing and growing trend of the worldwide sales in this sector) for these past years is not merely because the number of e-commerce companies had been increasing on an annual basis, nor only because that the number of visitors and consumers who are buying products or services from e-commerce websites keeps increasing, but mainly because thos consumers are coming back to the same companies (where they're purchasing their products from) and keeps repeating the same purchasing activities form the same companies. Known as Loyalty, which could be roughly understood as people or consumers' attitude or behavior to re-purchase a product from the same provider for an extended period of time, Loyalty is actually the main factor which allow e-commerce companies to prosper, which in turn will 
bring a positive impact to the e-comemrce sector as a whole, and enabling it to become one of the fastest growing sector on earth. Loyalty itself is always be strongly associated with consumers' intention to repurchase (repurchase intention), which could be defined as people or consumers' personal and strong intention to re-purchase or re-buy a product from the same companies in the future.

Repurchase intention plays an incredibly important role in affecting company's success of survivability in the industry, since it not only enable the company to continuously retain it's customers, drive it's customers' buying habit toward the company or extracting a maximum amount of profit from the same customers for a long period of time, but it also discourage customers to purchase a similar product or service from the competitors (Keni et al., 2018; Wilson, 2018). Therefore, it is understandable of why repurchase intention and loyalty had established themselves as two of the most studied variables in the history of marketing, since both variables play a crucial role in determining the effectiveness of the companies' marketing strategies, and ultimately, play an important role in determining companies' success and market share within the industry.

As there are quite a lot of variables which could affected loyalty or consumers' intention to repurchase, there are actually 4 (four) variables which had a strong, crucial and inseparable role in affecting customer loyalty or consumers' intention to rebuy a product from the same company in the e-commerce sector, which are perceived usefulness, perceived ease of use, trust and satisfaction. Perceived usefulness (PU) could be understood as people's judgement on whether or not the new technology will boost the quality of their life as a whole in a significant manner, while perceived ease of use (POU) could be understood as people's assessment on whether or not it was difficulty to learn and adopt the technologies (Dong et al., 2017; Han et al., 2020). People had a strong tendency to abandon using or adopt the new technologies when they felt that the technologies were incredibly complex and incredibly difficult to learn, which might hinder people's intention to use or implement the technologies in their life. Furthermore, people will most likely to stop or not using a new technology too if people (which serve as a potential customer and user of the technology) felt that the technology do little to affect or make their daily activities become easier or more efficient. Furthermore, if people perceive the new technology to be "no different" with the method that they're currently implement, then without a doubt, people will most probably re-think or re-question their intention to adopt the technology. Therefore, both of these variables had been largely deemed to have a significant impact on loyalty or consumers' repurchase intention in the e-comemrce sector, since such sector mainly and largely deal with the adoption and the implementation of new technologies.

Furthermore, both trust and customer satisfaction had also been deemed as two of the most studied variable in the field of marketing, and had long been understood as two variables which play significant roles in affecting customer loyalty and repurchase behavior across all industries. Could be defined as people's state of belief that the company will do exactly what it has promise to do to the customers, trust also plays an incredibly important and significant roles in affecting customers' repurchase behavior in the e-commerce sector, since all transactions and communications which were conducted in the e-commerce environment will be fully virtual, then it requires a strong level of trust within both parties (both the seller and the buyer) to trust each other in order to enable such transaction to be completed (Kartika et al., 2019). Therefore, when people trust the seller, then there's a high 
probability that they will put their trust to the e-commerce company, which will ultimately motivate them to make or engage in another transactional activities with the company.

Furthermore, other than trust, customer satisfaction also plays an incredibly crucial role in affecting customer loyalty and intention to repurchase toward the same company in the future (Menidjel et al., 2017). Most often defined as people or consumers' sense of delight in which the expectation that the consumers had toward the company exceeded by the true quality of the product or service that the company offered, satisfaction had been extensively studied and understood as one of the variable which mostly plays a significant role in affecting people's intention of whether or not to re-buy or re-visit the same company in the future. Furthermore, the role of satisfaction could be stronger felt in an industry which basically has a lot of competitors competing for the same group of consumers in the same industry. Therefore, it should be noted that each companies was required (or strongly suggested) to understand the notion or the importance of satisfaction, and it's role in affecting customer loyalty, particulary in the e-commerce sector which experience the growing or increasing number of newly-established companies on an annual basis.

Based on the explanations stated above, author was interested in assessing whether or not perceived usefulness and perceived ease of use positively affected consumers' repurchase intention in the e-commerce sector in Indonesia, both in a direct and indirect manner through trust and customer satisfaction

\section{THEORETICAL REVIEW}

Perceived Usefulness (PU). Perceived usefulness could be understood as people's judegement on whether their decision to use or implement a specific technology is advantageous for themselves (Tojib and Tsarenko, 2012; Stocchi et al., 2019; Wilson, 2019). Furthermore, (Ozturk, 2016) define Perceived Usefulness as people's intention of using a new technology in which an people put a strong sense of belief that the new technology will improve their job performance. Based on these definitions, author define perceived usefulness as consumers or people's judgement in which they believe that the tehcnologies that they're about to adopt will improve the quality of their job or activities.

Perceived Ease of Use (POU). Perceived ease of use could be understood as the extent in which whether or not using a specific system is easy (Dong et al., 2017). Furthermore, (Ha and Stoel, 2009) and (Stocchi et al., 2019) define perceived ease of use as consumers' feel of effortlessness (and convenience) while using a specific technology. Therefore, based on these definitions, author would like to define perceived ease of use as people of consumers' judgement in which the technologies that they about to implement will be easy to learn and easy to use.

Trust. Trust could be understood as people's confidence that the company or partner that they're interacting with possess honesty, credibility and benevolence that will be beneficial for both parties involved (Reza et al., 2020). Furthermore, trust could also be understood as Trust has been defined as the people's intention to accept all risks and vulnerability associated with doing a transaction with the other party which were based on the positive expectations that one had for the other party (Issock et al., 2020). Therefore, based on all of these definitions, author could like to define trust as people or consumers' level of beliefs 
that the other party or company (with whom the consumers are conducting a transaction with) won't betray or disappoint the promise that had been agreed beforehand.

Customer Satisfaction. (Both, 1980) and (Han et al., 2020) defined customer satisfaction as people's personal evaluation and judgement regarding their experience with the company, in which, such judgement was derived on whether or not people's level of expectation had been successfully surpassed by the company. Moreover, (Japutra et al., 2015) define Satisfaction as consumer's judgment that a product or service will fulfill consumers' need and expectation once the product or service was consumed or used by the consumers. Based on these definitions, author would like to define customer satisfaction as consumers' delight toward a company which derived from the fact that the product or service offered by the company had fulfilled the criteria set by the consumer for the product or service.

Repurchase Intention. Repurchase Intention is customer's personal assessment of whether or not customer will repeat another purchasing or transactional activities from the same provider in the future (Hellier et al., 2003; Li, 2015). Similarly, (Wilson et al., 2019) define Repurchase Intention as customers' consideration or intention toward the same company in the future, in which customers will assess whether to re-buy or re-purchase the product in the future. Based on these definitions, author would like to define repurchase intention as people's judgement and consideration on whether or not to re-engage on another transactional or interactional activities with the same companies in the future.

\section{Hypotheses Development}

The Effect of PU and POU on Repurchase Intention. Previous study by (Guriting and Ndubisi, 2006) in the Malaysian Banking sector had found that both Perceived Usefulness and Perceived Uase of Use play significant and positive roles in affecting customers' behavioral intention to re-engage in another transactional activities with the same bank. Furthermore, another study which was conducted by (Stocchi et al., 2019) in the Mobile Apps Sector in the UK had also found that either Perceived Usefulness and Perceived Ease of Use had a positive and significant impact toward customers' usage intention toward a mobile app, which ultimately will affect their intention to re-use the same app in the future. Similarly, another research conducted by (Dong et al., 2017) in China also generate similar results, in which both perceived usefulness and perceived ease of use have a positive impact on people's intention ti use and re-use the same technology

Based on these previous studies, the first and second hypothesis could be posited as follows:

H1: Repurchase Intention Was Positively Affected by Perceived Usefulness.

H2: Repurchase Intention Was Positively Affected by Perceived Ease of Use.

The Impact of Trust and Customer Satisfaction toward Repurchase Intention. Previous studies conducted by both (Kataria and Saini, 2019) in India and (Han et al., 2020) in South Korea had concluded that Customer Satisfaction had a positive impact toward 
Consumers' Intention to Re-Visit the same shop or company in the future time. Similarly, another studes conducted by (Brakus et al., 2009) and (Boenigk and Helmig, 2013) had found that satisfaction positively affected customer's intention to re-buy the product from the same organization, which also indicate that customer's level of loyalty will increase as their level of satisfaction toward the company strengthened.

Furthermore, regarding the effect of trust toward consumers' intention to re-purchase, previous study conducted by (Lim et al., 2019) in the Malaysian Social Media sector had concluded that indirectly, repurchase intention was significantly affected by trust while being mediated by customer engagement. Another study by (Agag et al., 2019) had also found that trust plays an integral and significant role in affecting people or customer's intention to book (and ultimately re-book) their hotels or accomodations from the same providers in the future. Based on all of these studies, the third and fourth hypothesis could be posited as follows:

H3: Repurchase Intention Was Positively Affected by Trust.

H4: Repurchase Intention Was Positively Affected by Customer Satisfaction.

The Effect of PU and POU on Repurchase Intention Through Trust and Customer Satisfaction. Previous study by (Daud et al., 2018) in Indonesia had a significant effect of PU on Satisfaction, which in turns brings a positive impact toward Loyalty and Customer intention to Repurchase from the same Company. Similarly, Perceived Ese of Use was also revealed to have a Positive and Significant Impact toward Trust, which ultimately turns out to have a significant impact toward Loyalty. Based on this study, Author would like to posit the fourth and fifth hypothesis as follows:

H5: Trust Was Positively Affected by Perceived Usefulness.

H6: Trust Was Positively Affected by Perceived Ese of Use.

H7: Customer Satisfaction Was Positively Affected by Perceived Usefulness.

H8: Customer Satisfaction Was Positively Affected by Perceived Ese of Use.

H9: Repurchase Intention Was Positively Affected by Perceived Usefulness Through Customer Satisfaction.

H10: Repurchase Intention Was Positively Affected by Perceived Ease of Use Through Customer Satisfaction.

H11: Repurchase Intention Was Positively Affected by Perceived Usefulness Through Trust.

H12: Repurchase Intention Was Positively Affected by Perceived Ease of Use Through Trust. 


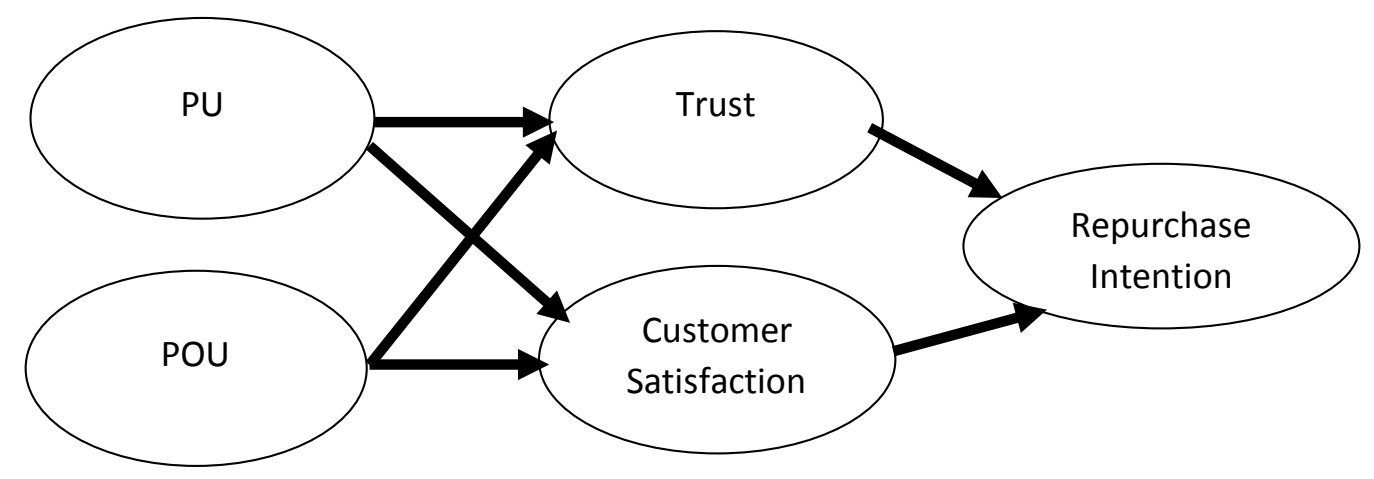

Figure 1. Research Figure

Source: Author's Personal Conception (2020)

\section{METHODS}

Measures. Survey Method was utilized on this study, in which, all of the data that which were required to be collected in order to ensure the completion of thus study were collected using Questionnaires. All of the Questionnaires were both Administered Personally and Electronically to all of the respondents.

Regarding all of the indicators used to assess each variable in this study, a total of 20 indicators or items were used in this study, in which, each variable was reperesented by 4 (four) indicators. A total of 4 (four) Indicators representing Variable Perceived Usefulness and 4 (four) indicators representing variable Perceived Ease of Use were adapted from (Dong et al., 2017) and (Stocchi et al., 2019). Furthermore, a total of 4 (four) indicators explaining variable trust and a total of 4 (four) indicators representing variable customer satisfaction were adapted from (Dagger and O'Brien, 2010) and (Wilson and Christella, 2019), and a total of 4 (four) indicators which represent Repurchase Intention were adapted from (Dong et al., 2017), (Wilson and Keni, 2018) and (Wilson et al., 2019).

Meanwhile, regarding the measurement scale which was implemented in this study, a Five-Point Likert Scale was implemented in this research, in which respondents were required to give their respond regarding each statement presented on the questionnaire, in which the responses varied from " 1 " which indicate that the respondent is strongly disagree toward the statement, "2" which indicate that the respondent is disagree toward the statement, "3" to reflect which indicate rhe respondent's neutrality toward the statement, "4" which indicate that the respondent is agree toward the statement, and " 5 " which finally indicate that the respondent is strongly agree toward the statement.

Sample and Procedure. 250 respondents joined this study, in which, all respondents who have been chosen to participate in this study need to fulfill the following criteria: All respondents are those who've made any purchasing activities through any C2C ECommerce websites at least five times for the past 1 year. Furthermore, all of the respondents who are participating in this study were Indonesians. Regarding the sampling method used on this study, convenience sampling method was implemented in thus study to ensure that all of the data were fully and completely collected in order for this study to be completed. 
After gathering all of the data from the respondents, an analysis regarding the profile of the respondents was commenced in order to better understand the general characteristics of the respondents who participate in this study. From a total of 250 respondents, it was revealed that a total of 123 respondents (49.2\%) are Males, and that the rest of the respondents are Female (127 respondents or $50.8 \%$ of the respondents). Furthermore, most of the respondents are students (which comprises of 167 respondents or $66.8 \%$ of the respondents) and that most respondents who participate in this study have at least completed a purchasing activities toward any $\mathrm{C} 2 \mathrm{C}$ e-commerce websites at least 5-10 times for the last 1 Year (182 respondents or around 72.8\%). These results illustrate that all respondents were quite active in conducting transactional activities in the e-commerce market for the last 1 Year.

After conducting an analysis regarding the profile of the respondents, all of the data then were further assessed in order to ensure the usability of the data which will be analyzed in order to find out the findings of this study. Out of 250 data which were collected from the respondents, after conducting further and thorough analysis, a total of 14 data need to be omitted due to the incomplete data filings. Therefore, a total of 236 data were determined to be usable and could be further analyzed in this study.

\section{RESULTS}

All of the 236 data that have been collected, sorted and assessed (in order to ensure it's usability, validity and reliability) then were analyzed using PLS-SEM with the help of SmartPLS 3.2.8 software. In the PLS-SEM method, there are 2 (two) main steps which needed to be conducted in this analysis, which are the outher mode analysis and the inner model analysis. Outer model analysis need to be conducted in order to assess or determine whether or not the data and the model of this study were Valid and Reliable. Meanwhile, the inner model analysis was conducted in order to understand the relationships between variables. Furthermore, the inner model analysis was also conducted in order to find out whether or not hypotheses were supported. Only if the model and the data had fulfilled the outer model criteria that the Inner model analysis could be conducted.

Outer Model Analysis. Outer model analysis was conducted in order to ensure that the model and the data were Valid and Reliable. Several aspects that needs to be fulfilled in order to ensure that the model and data had fulfilled the outer model analysis, which are: the factor loadings of each items needs to be greater than 0.5; the value of AVE and composite reliability of each variables need to be greater than 0.5 and 0.7 respectively; the value of AVE of each latent construct need to be higher than the construct's highest squared correlation with any other latent construct. Based on the results of the outer model analysis, it could be seen from the results that were presented on table 1 and 2 that all results have matched the given criteria, thus ensuring that all criteria in the outer model analysis had been fulfilled. This conclusion then indicate that the Inner Model Analysis could be conducted afterwards. 
Table 1. Outer Model Analysis Results

\begin{tabular}{|c|c|c|c|c|}
\hline Variables & Items & Factor Loadings & AVE & $\mathbf{C R}$ \\
\hline \multirow{4}{*}{ Perceived Usefulness } & PU1 & 0.813 & \multirow{4}{*}{0.539} & \multirow{4}{*}{0.827} \\
\hline & PU2 & 0.718 & & \\
\hline & PU3 & 0.729 & & \\
\hline & PU4 & 0.753 & & \\
\hline \multirow{4}{*}{ Perceived Ease of Use } & POU1 & 0.839 & \multirow{4}{*}{0.570} & \multirow{4}{*}{0.884} \\
\hline & POU2 & 0.854 & & \\
\hline & POU3 & 0.806 & & \\
\hline & POU4 & 0.817 & & \\
\hline \multirow{4}{*}{ Trust } & TR1 & 0.765 & \multirow{4}{*}{0.509} & \multirow{4}{*}{0.761} \\
\hline & TR2 & 0.699 & & \\
\hline & TR3 & 0.772 & & \\
\hline & TR4 & 0.783 & & \\
\hline \multirow{4}{*}{ Customer Satisfaction } & CS1 & 0.731 & \multirow{4}{*}{0.524} & \multirow{4}{*}{0.782} \\
\hline & $\mathrm{CS} 2$ & 0.852 & & \\
\hline & $\mathrm{CS} 3$ & 0.707 & & \\
\hline & $\mathrm{CS} 4$ & 0.723 & & \\
\hline \multirow{4}{*}{ Repurchase Intention } & RI1 & 0.813 & \multirow{4}{*}{0.533} & \multirow{4}{*}{0.849} \\
\hline & RI2 & 8.867 & & \\
\hline & RI3 & 0.796 & & \\
\hline & RI4 & 0.825 & & \\
\hline
\end{tabular}

Table 2. Discriminant Validity Analysis

\begin{tabular}{c|c|c|c|c|c}
\hline & CS & PU & POU & TR & RI \\
\hline CS & $\mathbf{0 . 7 6 2}$ & & & & \\
\hline PU & 0.514 & $\mathbf{0 . 8 4 6}$ & & & \\
\hline POU & 0.446 & 0.631 & $\mathbf{0 . 8 0 1}$ & & \\
\hline TR & 0.609 & 0.541 & 0.682 & $\mathbf{0 . 8 5 6}$ & \\
\hline RI & 0.513 & 0.618 & 0.555 & 0.574 & $\mathbf{0 . 7 4 9}$ \\
\hline
\end{tabular}

Inner Model Analysis and Hypotheses Testing. After completing the Outer Model Analysis, the Inner model analysis was further conducted in order to determine the relationship between variables, and to measure whether or not the hypotheses proposed in this research were supported. T-value was implemented as the basis to determine whether or not to accept the hypotheses proposed in this study. A hypothesis will be supported if the t-value of the hypothesis is greater than 1.96, while in the other hand, a t-value of less than 1.96 indicate that the hypothesis should be rejected. The results of the Hypotheses Testing were presented on Table 3 dna 4 respectively. 
Table 3. Path Coefficient Analysis

\begin{tabular}{c|c|c|c}
\hline Path Analysis & t-value & Sig.value & Results \\
\hline PU $\rightarrow$ Trust & 3.127 & 0.000 & Significant \\
\hline PU $\rightarrow$ Customer Satisfaction & 3.004 & 0.000 & Significant \\
\hline POU $\rightarrow$ Trust & 1.984 & 0.046 & Significant \\
\hline POU $\rightarrow$ Customer Satisfaction & 2.038 & 0.035 & Significant \\
\hline PU $\rightarrow$ Repurchase Intention & 2.856 & 0.011 & Significant \\
\hline POU $\rightarrow$ Repurchase Intention & 2.419 & 0.017 & Significant \\
\hline Trust $\rightarrow$ Repurchase Intention & 4.587 & 0.000 & Significant \\
\hline Customer Satisfaction $\rightarrow$ Repurchase Intention & 3.642 & 0.000 & Significant \\
\hline PU $\rightarrow$ Trust $\rightarrow$ Repurchase Intention & 2.954 & 0.008 & Significant \\
\hline $\begin{array}{c}\text { PU } \rightarrow \text { Customer Satisfaction } \rightarrow \text { Repurchase } \\
\text { Intention }\end{array}$ & 2.188 & 0.033 & Significant \\
\hline POU $\rightarrow$ Trust $\rightarrow$ Repurchase Intention & 2.079 & 0.035 & Significant \\
\hline $\begin{array}{c}\text { POU } \rightarrow \text { Customer Satisfaction } \rightarrow \text { Repurchase } \\
\text { Intention }\end{array}$ & 2.368 & 0.029 & Significant \\
\hline
\end{tabular}

Table 4. Hypotheses testing results

\begin{tabular}{|c|c|c|c|}
\hline & Hypotheses & t-value result & Hypotheses Result \\
\hline H1 & $\begin{array}{l}\text { Perceived Usefulness had a Positive Impact on } \\
\text { Repurchase Intention }\end{array}$ & 2.856 & Supported \\
\hline H2 & $\begin{array}{c}\text { Perceived Ease of Use had a Positive Impact on } \\
\text { Repurchase Intention }\end{array}$ & 2.419 & Supported \\
\hline H3 & $\begin{array}{l}\text { Trust Had a Positive Impact on Repurchase } \\
\text { Intention }\end{array}$ & 4.587 & Supported \\
\hline H4 & $\begin{array}{c}\text { Customer Satisfaction Had a Positive Impact on } \\
\text { Repurchase Intention }\end{array}$ & 3.642 & Supported \\
\hline H5 & $\begin{array}{c}\text { Perceived Usefulness Had a Positive Impact on } \\
\text { Trust }\end{array}$ & 3.127 & Supported \\
\hline H6 & $\begin{array}{c}\text { Perceived Ease of Use Had a Positive Impact } \\
\text { on Trust }\end{array}$ & 1.984 & Supported \\
\hline H7 & $\begin{array}{c}\text { Perceived Usefulness Had a Positive Impact on } \\
\text { Customer Satisfaction }\end{array}$ & 3.004 & Supported \\
\hline H8 & $\begin{array}{l}\text { Perceived Ease of Use Had a Positive Impact } \\
\text { on Customer Satisfaction }\end{array}$ & 2.038 & Supported \\
\hline H9 & $\begin{array}{c}\text { Perceived Usefulness Had a Positive Impact on } \\
\text { Repurchase Intention Through Customer } \\
\text { Satisfaction }\end{array}$ & 2.188 & Supported \\
\hline H10 & $\begin{array}{l}\text { Perceived Ease of Use Had a Positive Impact } \\
\text { on Repurchase Intention Through Customer } \\
\text { Satisfaction }\end{array}$ & 2.368 & Supported \\
\hline H11 & $\begin{array}{l}\text { Perceived Usefulness Had a Positive Impact on } \\
\text { Repurchase Intention Through Trust }\end{array}$ & 2.954 & Supported \\
\hline H12 & $\begin{array}{l}\text { Perceived Ease of Use Had a Positive Impact } \\
\text { on Repurchase Intention Through Trust }\end{array}$ & 2.079 & Supported \\
\hline
\end{tabular}


Based on the results of the analyses presented on table 3 and 4, author would like to conclude that all hypotheses which were proposed at the beginning of this study were supported. The first and second Hypotheses formulate that Perceived Usefulness and Perceived Ease of Use had a Positive Impact toward Repurchase Intention. Since the t-value generated by both relationships turned out to be greater than 1.96 (2.856 and 2.419 respectively), then Author would like to conclude that the first and second hypotheses were supported (H1 and H2 Supported). Furthermore, the third and fourth hypotheses formulate that Trust and Customer Satisfaction had a Positive Impsct toward Repurchase Intention. Since the t-value generated by both relationships turned out to be greater than 1.96 (4.587 and 3.642 respectively), then Author would like to conclude that the third and fourth hypotheses were supported as well (H3 and H4 Supported).

The fifth, sixth, seventh and eighth hypotheses proposed that both Percieved Usefulness and Perceived Ease of Use had a positive impact toward both Trust and Customer Satisfaction. Since the t-value of all of these hypotheses were greated than 1.96, then Author would like to conclude that the Fifth, Sixth, Seventh and Eighth hypotheses were supported (H5, H6, H7 and H8 Supported). Furthermore, the ninth, tenth, eleventh and twelfth hypotheses formulate that both Perceived Usefulness and Perceived Ease of Use had a Positive Impact on Intention to Repurchase through Trust and Satisfaction. Therefore, in order to test these hypotheses, the Mediation analysis was conducted in order to determine whether or not Satisfaction and Trust mediate the relationships between both Perceived Usefulness, Perceived Ease of Use and Repurchase.

Based on the results of the Mediation analysis, it was found out that the direct effect of both perceived usefulness and perceived ease of use toward repurchase were significant, while the indirect effect of perceived usefulness and perceived ease of use toward repurchase while being mediated by both Trust and Satisfaction were also significant. Therefore, based on these findings, it could be concluded that both Trust and Satisfaction partially mediate the impact of perceived usefulness and perceived ease of use toward repurchase. Therefore, the Ninth, Tenth, Eleventh and Twelfth Hypothesis were Supported (H9, H10, H11 and H12 Supported). Therefore, based on these results, author would like to conclude that all Hypotheses were supported in this study.

Table 5. Indirect and Total Effects Analysis

\begin{tabular}{c|c}
\hline Relationship between Variables & t-value (Indirect effect) \\
\hline PU $\rightarrow$ Trust $\rightarrow$ Repurchase Intention & 2.954 \\
\hline PU $\rightarrow$ Customer Satisfaction $\rightarrow$ Repurchase Intention & 2.188 \\
\hline PU $\rightarrow$ Repurchase Intention & 2.856 \\
\hline POU $\rightarrow$ Trust $\rightarrow$ Repurchase Intention & 2.079 \\
\hline POU $\rightarrow$ Customer Satisfaction $\rightarrow$ Repurchase Intention & 2.368 \\
\hline POU $\rightarrow$ Repurchase Intention & 2.419 \\
\hline
\end{tabular}

\section{DISCUSSION}

This study was conducted in order to determine whether or not perceived usefulness and perceived ease of use had a positive impact on consumers' intention to repurchase, both directly and indirectly through trust and satisfaction. Based on the results of the data 
analyses, author would like to conclude that both perceived usefulness and ease of use indeed positively affected consumers' intention to repurchase, both in a directly and indirect manner through trust and satisfaction. In regard with this findings, people or consumers tend to use or adopt a new technology only if they felt that the technology will be beneficial for their life, or that the new technology will bring a positive impact to their work, in which, people tend to adopt or use a new technology only if they felt that the technologt will boost the quality of efficiency of their works.

However, not only that it should bring or induce a specific additional value to all of the users, such technologies shouldn't be perceived by people as "Too Complex" or "Too Difficult to Learn With", since when people perceive a Technology to be "Too Difficult", "Too Complicated", or "Will took a lot of time" for the users to learn, that it is most likely that people will abandon their intention of using or learning such technology, and will prefer to go back by doing it in the Old Way. Therefore, it is incredibly important for e-commerce companies to create a new system which will ease or improve the efficiency and eeffectiveness of the transactional or communicarional activities between customers and sellers while also ensure that it won't took a lot of time for the sellers, buyers or people (who could become a potential seller or buyer for that company) to observe and learn such technologies in order to ensure that they're be able to use it in a short period of time.

Furthermore, based on the results of this study, people's feeling or perception, not only regarding whether or not such technology will improve the quality of their life or work, but also regarding whether or not it was difficult to learn the technology could positively affect their trust and level of satisfaction toward the system and the company, which inturns could determine and shape their intention on whether or not to re-engage in another transactional activities toward the company. Therefore, it was incredibly important for companies to look out for these two (2) main variables which have been revealed to have a positive and significant impact on consumers' trust, satisfaction and ultimately, intention to repurchase from the same e-commerce website in the future.

Other than finding that both the perceived usefulness and perceived ease of use had an indirect effect on trust, satisfaction and repurchase intention, the results of this study also underlined and found that perceived usefulness act as a stronger variabel which affect consumers' intention to repurchase. This conclusion could be derived from the fact that the t-value (which denotes the strength or the significance of the relationships) between perceived usefulness toward repurchase intention is higher than the t-value between perceived ease of use and repurchase intention. This finding then underlined that most Indonesians are willing to use a new system or technology if they found that the new technology could prove to be beneficial in adding osme values or increase the quality of their life. However, it should also be noted that consumers or people's perception regarding how long and how difficult is is to learn a new technology also serves as an equally important factor, since ease of use had been found to have a positive relationship with repurchase intention.

In the other hand, both trust and satisfaction also turns out to be a positive and significant mediator regarding the relationships between perceived usefulness and ease of use toward consumers' intention to repurchase. These results show that since not only that perceived ease of use and usefulness could bring a positive direct impact on repurchase, but it also shows that as people had a positive perception toward the technology or the systems adopted by the company (which, in case of this study, by e-commerce company), their level 
of trust and satisfaction and trust tend to be boosted, which resulted in the increase of people's intention to repurchase form the same company in the future. Therefore, it should be noted that consumers' negative perception regarding the safety and the complexity of the system adopted by the company could not only resulted in the consumers' intention to purchase a product from the other companies, but it could also lower their satisfaction and trust level, which in the end could bring a negative consequences for the company as the number of consumers' that a company had could decrease.

\section{CONCLUSION}

Theoretical Implications. Based on the results obtained in this study, author would like to conclude that both PU and POU positively affect Consumers' Intention to Repurchase, both in a Direct and Direct Manner through Trust and Satisfaction. The findings of this study bring a significant value to the development of the theories or literatures concerning the relationships of these variables, in which as most study try to understand the impact of PU and POU as Mediators toward either consumers' purchase intention or repurchase behavior, this study try to understand the impact of perceived usefulness and ease of use as independent variables toward people's repurchase behavior. Moreover, this study was also try to understand how the relationships between these three variables when trust and satisfaction were added as the mediator, which only a few study have been trying to do. Therefore, the results of this study contribute to the development of the literature in the context of Marketing, in which, in the e-commerce sector, both perceived usefulness and ease of use had a significant impact toward repurchase intention, both directly and indirectly while being mediated by satisfaction and trust.

Managerial Implications. The results of this study serve as an important reminder for ecomemrce companies to further ensure that all of the systems and technologies which were being implemented (or about to being implemented) by each company to it's respective ecommerce website won't be too complicated to be studied by people, buyers or the sellers, as there's a high risk that people will leave the website or move out to buy products or services to the other e-comemrce websites if the system or features implemented to the website was deemed too difficult to be understood.

Furthermore, each and every e-commerce companies also need to understand and pay a significant amount of attention regarding the value-added of the technology that were being implemented and offered to people and customers, since if there's no additional value that customers could get from using the system, or by buying products or services through e-commerce, then people will perceive that they're no benefits that they could generate or felt by using the system and buying the product through a specific e-commerce website, which could motivate them to not buying things from the website for a indefinite amount of time. Therefore, it must be noted by all e-commerce companies that they need to thoroughly understand the impact and the importance of these variables in order to ensure that they'll aw $=$ lways be in a strategic position in the Industry.

Research Limitations and Directions For Further Research. Despite the rigorous nature of this study, there are still several limitations existed on this study. First of all, this study was conducted in the e-commerce sector in Indonesia, which might indicate that the results 
of this study might not be able to be generalized properly on the other countries. Therefore, a follow up study which try to re-test the relationships of these variables on the other countries was strongly recommended for future study. Secondly, the number of respondents participating in this study were 250, which indicate that these numbers might nor wellrepresent the entire population. Therefore, author suggest for future study to conduct a study using this model by increasing the number of respondents participating in the study.

\section{REFERENCES}

Agag, G.M., Khashan, M.A., Colmekcioglu, N., Almamy, A., Alharbi, N.S., Eid, R., Shabbir, H. and Abdelmoety, Z.H.S. (2019). "Converting hotels website visitors into buyers: How online hotel web assurance seals services decrease consumers' concerns and increase online booking intentions", Information Technology \& People, Vol. 33 No. 1, pp. 129-159. https://doi.org/10.1108/ITP-12-2017-0446.

Boenigk, S. and Helmig, B. (2013). "Why do donors donate? Examining the effects of organizational identification and identity salience on the relationships among satisfaction, loyalty, and donation behavior", Journal of Service Research, Vol. 16 No. 4, pp. 533-548.

Brakus, J.J., Schmitt, B.H. and Zarantonello, L. (2009). "Brand experience: what is it? How is it measured? Does it affect loyalty?". Journal of Marketing, Vol. 73 No. 3, pp. 5268.

Dagger, T.S. and O'Brien, T.K. (2010). "Does experience matter? Differences in relationship benefits, satisfaction, trust, commitment and loyalty for novice and experienced service users", European Journal of Marketing, Vol. 44 No. 9/10, pp. 1528-1552. https://doi.org/10.1108/03090561011062952.

Daud, A., Farida, N., Andriyansah, A., and Razak, M. (2018). Impact of customer trust toward loyalty: the mediating role of perceived usefulness and satisfaction, Journal of Business and Retail Management Research, Vol. 13(2), pp. 235-242.

Dong, X., Chang, Y., Wang, Y. and Yan, J. (2017). "Understanding usage of Internet of Things (IOT) systems in China: Cognitive experience and affect experience as moderator", Information Technology \& People, Vol. 30 No. 1, pp. 117-138. https://doi.org/10.1108/ITP-11-2015-0272.

Guriting, P. and Oly Ndubisi, N. (2006). "Borneo online banking: evaluating customer perceptions and behavioural intention", Management Research News, Vol. 29 No. 1/2, pp. 6-15. https://doi.org/10.1108/01409170610645402.

Ha, S. and Stoel, L. (2009). "Consumer e-shopping acceptance: antecedents in a technology acceptance model”, Journal of Business Research, Vol. 62 No. 5, pp. 565-571.

Han, H., Lee, K.-S., Song, H., Lee, S. and Chua, B.-L. (2019). "Role of coffeehouse brand experiences (sensory/affective/intellectual/behavioral) in forming patrons' repurchase intention: Impact of switching costs", Journal of Hospitality and Tourism Insights, Vol. 3 No. 1, pp. 17-35. https://doi.org/10.1108/JHTI-03-2019-0044.

Hellier, P.K., Geursen, G.M., Carr, R.A. and Rickard, J.A. (2003). "Customer repurchase intention: a general structural equation model", European Journal of Marketing, Vol. 37 Nos 11/12, pp. 1762-1800.

Issock Issock, P.B., Roberts-Lombard, M. and Mpinganjira, M. (2020). "The importance of customer trust for social marketing interventions: a case of energy-efficiency 
consumption", Journal of Social Marketing, Vol. ahead-of-print No. ahead-of-print. https://doi.org/10.1108/JSOCM-05-2019-0071.

Japutra, A., Keni, K. and Nguyen, B. (2015). "The impact of brand logo identification and brand logo benefit on Indonesian consumers' relationship quality", Asia-Pacific Journal of Business Administration, Vol. 7 No. 3, pp. 237-252. https://doi.org/10.1108/APJBA-10-2014-0124.

Kartika, T., Firdaus, A. and Najib, M. (2019). "Contrasting the drivers of customer loyalty; financing and depositor customer, single and dual customer, in Indonesian Islamic bank ", Journal of Islamic Marketing, Vol. ahead-of-print No. ahead-of-print. https://doi.org/10.1108/JIMA-04-2017-0040 .

Kataria, S. and Saini, V. (2019). "The mediating impact of customer satisfaction in relation of brand equity and brand loyalty: An empirical synthesis and re-examination", South Asian Journal of Business Studies, Vol. 9 No. 1, pp. 62-87. https://doi.org/10.1108/SAJBS-03-2019-0046.

Keni, K., Oktora, F. and Wilson, N. (2018). The Impact of Destination Image and Perceived Quality on Tourist Loyalty in the Indonesian Tourism Industry. In Proceedings of the 7th International Conference on Entrepreneurship and Business Management Volume 1: ICEBM Untar, pp. 67-75. 10.5220/0008488300670075.

Li, C.-Y. (2015). "Switching barriers and customer retention: Why customers dissatisfied with online service recovery remain loyal", Journal of Service Theory and Practice, Vol. 25 No. 4, pp. 370-393. https://doi.org/10.1108/JSTP-10-2013-0220.

Lim, X.-J., Cheah, J.-H., Waller, D.S., Ting, H. and Ng, S.I. (2019). "What s-commerce implies? Repurchase intention and its antecedents", Marketing Intelligence \& Planning, Vol. ahead-of-print No. ahead-of-print. https://doi.org/10.1108/MIP-032019-0145.

Menidjel, C., Benhabib, A. and Bilgihan, A. (2017). "Examining the moderating role of personality traits in the relationship between brand trust and brand loyalty". Journal of Product \& Brand Management, Vol. 26 No. 6, pp. 631-649. https://doi.org/10.1108/JPBM-05-2016-1163.

Oliver, R.L. (1980). "A cognitive model of the antecedents and consequences of satisfaction decisions", Journal of Marketing Research, Vol. 17 No. 4, pp. 460-469.

Ozturk, A.B. (2016). "Customer acceptance of cashless payment systems in the hospitality industry", International Journal of Contemporary Hospitality Management, Vol. 28 No. 4, pp. 801-817. https://doi.org/10.1108/IJCHM-02-2015-0073.

Retail e-commerce sales worldwide from 2014 to 2023 (in billion U.S. dollars). (2020, May 2). Retrieved June 4, 2020, from https://www.statista.com/statistics/379046/worldwide-retail-e-commerce-sales/.

Reza, S., Mubarik, M.S., Naghavi, N. and Rub Nawaz, R. (2020). "Relationship marketing and third-party logistics: evidence from hotel industry", Journal of Hospitality and Tourism Insights, Vol. ahead-of-print No. ahead-of-print. https://doi.org/10.1108/JHTI-07-2019-0095.

Stocchi, L., Michaelidou, N. and Micevski, M. (2019). "Drivers and outcomes of branded mobile app usage intention", Journal of Product \& Brand Management, Vol. 28 No. 1, pp. 28-49. https://doi.org/10.1108/JPBM-02-2017-1436.

Tojib, D. and Tsarenko, Y. (2012). "Post-adoption modeling of advanced mobile service use", Journal of Business Research, Vol. 65 No. 7, pp. 922-928. 
Wilson, N., Keni, K., and Tan, P.H.P. (2019). The Effect of Website Design Quality and Service Quality on Repurchase Intention in the E-commerce Industry: A CrossContinental Analysis, Gadjah Mada International Journal of Business, 21(2), 187222. https://doi.org/10.22146/gamaijb.33665.

Wilson, N., and Christella, R. (2019). An Empirical Research of Factors Affecting Customer Satisfaction: A Case of the Indonesian E-Commerce Industry, DeReMa Jurnal Manajemen, Vol. 14(1), pp. 21-44. http://dx.doi.org/10.19166/derema.v14i1.1108.

Wilson, N., and Keni, K. (2018). Pengaruh Website Design Quality dan Kualitas Jasa Terhadap Repurchase Intention: Variabel Trust Sebagai Variabel Mediasi, Jurnal Manajemen dan Pemasaran Jasa, Vol. 11 (2), pp. 291-310. http://dx.doi.org/10.25105/jmpj.v11i2.3006.

Wilson, N. (2018). The Impact of Service Quality and Brand Image Toward Customer Loyalty in The Indonesian Airlines Industry, Jurnal Manajemen Indonesia. Vol. 18 (3), pp. 222-234. https://doi.org/10.25124/jmi.v18i3.1734.

Wilson, N. (2019). The Impact of Perceived Usefulness and Perceived Ease-of-Use toward Repurchase Intention in the Indonesian E-Commerce Industry, Jurnal Manajemen Indonesia. Vol. 19 (3), pp. 241-249. https://doi.org/10.25124/jmi.v19i3.2412. 